\title{
THE AMERICAN JOURNAL OF
}

HORTICULTURE AND FLORICULTURE

VOLUME01 ISSUE04

\section{RESEARCH}

\section{Effects Of Ameliorate Fertilizer And Excrement With Phosphate Rock On Condition Of Redroot Pigweed}

\author{
Prof. Minja A.P. ${ }^{1}$, Prof. Rweyema C.L. ${ }^{2}$ \\ ${ }^{1}$ Department Of Horticulture Mubondo University, Dar Es Salaam \\ ${ }^{2}$ Sebastian Kolowa Memorial University, Tanzania
}

\begin{abstract}
A study was conducted in Iringa, Tanzania to judge the results of herb manure and fertilizerapplied alone or amended with Minjingu Phosphate Rock (MPR) as sources of N and P and their effects on vegetable condition attributes. the sector experiment was conducted employing a split plot style with 3 replications. Crop species shaped main plots, whereas plant food treatments set up the subplots. 2 redroot pigweed species (Redroot pigweedus cruentus and caryophylloid dicot genus hypochondriacus) were used. The treatments enclosed herb (Crotalaria ochroleuca), herb + MPR, compost, fertilizer+ MPR and NPK, that was used as a regular. Results indicated that change of fertilizeror herb with MPR increased P offer by twenty second and $100 \%$, severally. The tested materials considerably hyperbolic water-soluble vitamin, axerophthol and crude macromolecule content of redroot pigweed. Plants from plots treated with herb had considerably higher levels of macromolecule, calcium, vitamins $C$ and $A$ contents, compared to those fertile with compost. there have been important and positive correlations between soil on the market $\mathrm{N}, \mathrm{P}$, and uptake with macromolecule, calcium, iron, water-soluble vitamin and $\mathrm{A}$ content of redroot pigweed. because of the role of $\mathrm{Ca}$ in plasma membrane synthesis, it in all probability influenced the keeping condition of redroot pigweed. The high Ca content in MPR amended treatments hyperbolic the evaluated keeping condition attributes of redroot pigweed. it's thus suggested that the tested organic materials be adopted as sources of $\mathrm{N}$ and $\mathrm{P}$ within the organic production of redroot pigweed. Application of herb and fertilizerought to be supplemented with P sources like MPR so as to extend their P contents.
\end{abstract}

Key words: Organic farming, Minjingu phosphate rock, Vegetables, Condition.

Prof. Minja A.P. , Prof. Rweyema C.L. 


\section{THE AMERICAN JOURNAL OF}

\section{RESEARCH}

\section{Introduction}

Vegetables square measure smart sources of vitamins, minerals and proteins, all of that contribute to the nice health of individuals (Tindall, 1983). except their wholesome values, vegetables are sources of financial gain. Redroot pigweed (Redroot pigweedus spp.) is among the foremost unremarkably full-grown vegetable in Tanzania. it's full-grown exploitation each typical and organic farming strategies. For optimum yields, redroot pigweed demands high levels of soil chemical element (N) and phosphorus (P) (Tindall, 1983). this means that the only real use of organic materials for production of this vegetable crop in areas with low soil $P$, like Southern Highlands of Tanzania, might not offer adequate amounts of $P$ so requiring extra supply (Nziguheba et al., 2002). Phosphate rock (PR) is suitable to be used in organic farming because of its natural and slow P cathartic characteristics (Walker et al., 2006). However, rock phosphate is more practical once applied to perennial crop species than to the short-run annual crops like redroot pigweed. this is often as a result of the discharge of $P$ will increase with the time of contact between soil and PR. change of organic materials with PR increase soil on the market P through increased dissolution caused by the free acids from the mouldering matters.

The use of fertilizers affects the standard of agricultural product together with nutritionary composition (Roinila and Granstedt, 1995). chemical element fertilizers at high rates tend to extend nitrate accumulation, and reduce the content of water-soluble vitamin in several fruits and vegetables (Babik et al., 2002). However, most studies have solely connected fertilizers with yield or nutritionary worth responses while not clear relationship with the supply of soil nutrients. The distinction between convenience of nutrients from organic and inorganic sources and their relationship with condition of vegetables isn't terribly clearly understood. Since the plant roots absorb nutrients in easy ionic forms like NO3- and NH4+, there's no distinction whether or not they square measure derived from organic or mineral sources (Giller, 2002).

\section{Materials And Strategies}

The sector experiment was conducted at the Tanzania Tree Seed Agency (TTSA) centre set at seventy 49' S associate degreed $35041^{\prime} \mathrm{E}$ at an altitude of $1548 \mathrm{~m}$ on top of water level. The experiment was conducted from Sep 2000 to Sep 2002, and was continual thrice. Soil 


\section{THE AMERICAN JOURNAL OF}

\section{RESEARCH}

characterization was conducted at the start of the experiment. Soil samples were every which way collected at a depth of twenty $\mathrm{cm}$ to represent the experimental space.

\section{Experimental style and Preparation of Materials}

The field experiment was ordered get into a split plot style with 3 replications. Crop species set up the most plots, whereas plant food treatments shaped the subplots. 2 unremarkably fullgrown redroot pigweed species, redroot pigweed and redroot pigweed were used. plant food treatments included: (i) management (no plant food material added), (ii) compost, (iii) fertilizer+ MPR, (iv) herb manure, (v) herb manure + MPR, and (vi) NPK (standard).

Seeds of herb ochroleuca were directly seeded on the experimental plots at a rate of fifty $\mathrm{kg} / \mathrm{ha}$. herb plants were uprooted at flowering stage, sliced and incorporated into the soil. The MPR (49 kilo $\mathrm{P} / \mathrm{ha}$ ) was broadcast equally on the manure at the time of incorporation into the soil, to come back up with manure + MPR treatment. the speed of application for manure and fertilizerwas supported $\mathrm{N}$ content of those materials and $\mathrm{N}$ demand of redroot pigweed crop. Seeds of $\mathrm{A}$. cruentus and $A$. hypochondriacus were seeded at a spacing of thirty $\mathrm{cm}$ between rows and fifteen $\mathrm{cm}$ among rows. Plots used were three $\mathrm{m}$ wide and three $\mathrm{m}$ long, giving a plot size of nine money supply. Weeding and irrigation were done once necessary.

\section{Data assortment and Analysis}

Soil samples were collected from the plots when every harvest. The soil samples were analysed for on the market levels of $\mathrm{N}$ and $\mathrm{P}$. Tissue concentrations of $\mathrm{N}$ and $\mathrm{P}$ within the plant materials were determined following procedures made public by Okalebo et al. (1993). These values were then wont to cypher $\mathrm{N}$ and $\mathrm{P}$ uptake. 


\section{THE AMERICAN JOURNAL OF}

\section{RESEARCH}

Ten redroot pigweed plants every which way picked from every treatment were used for condition analysis. water-soluble vitamin content was resolute exploitation the two,6dichlorophenol-indophenol methodology (Plumer, 1974). axerophthol was resolute by the spectrophotometric methodology (AOAC, 1995). Iron and $\mathrm{Ca}$ contents were determined exploitation the atomic absorption spectrophotometric methodology (AOAC, 1995). chemical element content was resolute by exploitation the automatic Kjeldahl methodology (AOAC, 1995). chemical element content values were increased by an element half-dozen.25 to get crude macromolecule. For keeping quality, redroot pigweed leaf samples were washed, blanched, dried, prepacked in synthetic resin baggage and so hold on at temperature for twenty eight days.

\section{Results And Discussion}

Result of Treatments on convenience of $\mathrm{N}$ and $\mathrm{P}$ in Soil and Uptake by Redroot pigweed Plants

plant food materials considerably $(\mathrm{P}<0.05)$ improved convenience of $\mathrm{N}$ and $\mathrm{P}$ within the soil . Plots treated with NPK had the very best on the market N and P that's ascribed to higher solubility and thence higher rate of unharness of mineral $\mathrm{N}$ and $\mathrm{P}$ compared to the organic amendments. Variation within the rate and temporal arrangement of cathartic P among plant food materials may justify the high CV (\%) values ascertained on soil on the market $P$. the amount of variation shrivelled in future crop cycles because of build of $P$ within the organic treatments.

Effects of plant food Materials on the Keeping Condition of Redroot pigweed

Plants from all plant food treatments had considerably lower weight loss compared to the management. the burden loss by redroot pigweed, that is generally because of loss of wetness, may be associated with metallic element content of the plants. metallic element incorporates a important influence on the strength of plasma membrane in plants. though not considerably completely different, plants treated with herb, herb + MPR and NPK had lower weight loss as compared to different treatments because of higher Ca content . additionally, there was a extremely important $(P<0.01)$ correlation $(r=-0.621)$ between metallic element content in redroot plants and weed loss. 


\section{THE AMERICAN JOURNAL OF}

HORTICULTURE AND FLORICULTURE

\section{VOLUME01 ISSUE04}

\section{RESEARCH}

\section{Conclusions And Proposals}

From the results it will be terminated that application of organic materials, considerably hyperbolic soil on the market $\mathrm{N}$ and $\mathrm{P}$. Combination of phosphate rock with manure or fertilizerhyperbolic soil $\mathrm{P}$ offer compared to unamended treatments. The results indicate a detailed relationship between soil on the market nutrients, plant uptake and condition attributes of the take a look at vegetable crop. The distinction between organic and inorganic sources may be supported their completely different skills to unharness nutrients. because of its high Ca content, MPR amended treatments hyperbolic the evaluated keeping condition attributes of redrootpigweedvegetables.

\section{References}

1. Association of Official Analytical Chemists (AOAC). 1993. Official strategies of study. sixteenth edition.AOACInternationalArlington.

2. Elkner, R. Booij and J. Neeteson. 2001. The result of chemical element fertilization and irrigation on yield and condition ofbroccoli.ActaHorticulturae.

3. A.N., D.D. Kumbhar and S.Y. Daftardar. 1998. Rock phosphate with manure and farm yard manure as P-source for rice, bean crop sequence on lateritic soil.

4. C.K.K., C. Palm, and J.G. Mureithi. 1989. Legume cowl crops for soil fertility improvement within the East African Region. African Highland Initiative (AHI) Soils working party Report.

5. Giller, K.E. 2005. Targeting management of organic resources and mineral fertilizers. will we have a tendency to match scientists' fantasies with farmers' realities? In: Vanlauwe, B., J. Diels, N. Sanginga and R. Merckx, (Eds.). Integrated Plant Nutrient Management in BlackAfrica.

6. Lee, S.K. and A.A. Kader. 2000. Preharvest and postharvest factors influencing water-soluble vitamin content of farming crops. Postharvest Biology and Technology. 


\section{THE AMERICAN JOURNAL OF}

\section{RESEARCH}

7. Locascio, S.J., W.J. Wiltbank, D.D. Gull, and D.N. Maynard. 1984. Fruit and vegetable condition as full of chemical element nutrition. In: R. D. Hauck (ed.). chemical element in Crop Production. 